\title{
Combining Ability Analysis in Sponge gourd [Luffa cylindrica (Roem.) L.]
}

\author{
Sanjeev Kumar ${ }^{1 *}$, V.J. Bhatiya ${ }^{2}$ and Sanjay Kumar ${ }^{1}$ \\ ${ }^{1}$ Department of Genetics and Plant Breeding, Department of Seed Science and Technology, \\ Junagadh Agricultural University, Junagadh-362001 (Gujarat), India
}

*Corresponding author

\section{A B S T R A C T}

\begin{tabular}{|l|}
\hline K e y w or d s \\
Sponge gourd, \\
Combining ability, \\
Diallel
\end{tabular}

\section{Keywords}

Sponge gourd, Combining ability, Dialle

\section{Article Info}

26 April 2018

10 May 2018

\begin{abstract}
A $10 \times 10$ diallel analysis in $\mathrm{F}_{1}$ generation excluding reciprocals in sponge gourd [ $\mathrm{Luffa}$ cylindrica (Roem.) L.] was carried out to identify good combiners and best combinations along with its heterotic effect. Mean square due to GCA and SCA were significant indicated that both additive and non-additive type of gene effects played an important role in the inheritance of all these traits under studied with preponderance of non-additive gene action for all the traits except fruit length. Parents Pusa Chikni, ASGS 08-37, ASGS 06-30 and JSG 05-7 were found to be the good general combiners for fruit yield and some of the yield contributing characters, whereas, parents ASGS 08-39 was found to be good combiner for earliness and ten fruit weight. The three cross combinations viz., Pusha chikni X ASGS 08-37, ASGS 08-37 x ASGS 08-39 and ASGS 08-40 x JSG 05-4 were found to be good specific combiners for fruit yield per vine and would be exploited for heterosis breeding in sponge gourd.
\end{abstract}

\section{Introduction}

Combining ability analysis is an important tool in the hands of the plant breeders to identify good lines in their breeding material and further to select promising hybrid combinations to develop suitable hybrids from them. The relative amount of general combining ability (GCA) and specific combining (SCA) effects play a vital role in planning the appropriate and sound breeding programme. Therefore, the present investigation was carried out to estimate GCA and SCA effects and to know the type of gene action governing fruit yield and its component traits of ten diverse sponge gourd genotypes and their combinations.

\section{Materials and Methods}

The experimental material comprised of parents and their $F_{1}$ 's derived by crossing ten different genotypes of sponge gourd (Pusa Chikni, GSG 1, ASGS 08-40, ASGS 08-38, ASGS 08-37, ASGS 08-39, ASGS 06-30, ASGS 02-12, JSG 05-7 and JSG 05-4) in a diallel fashion excluding reciprocals. The experiment was laid out in a randomized block design with three replications during summer2011 at Instructional Farm JAU., Junagadh. 
The plants were spaced at a distance of $2.0 \mathrm{~m}$ between rows and $1.0 \mathrm{~m}$ within a row. Five plants of each parents and $F_{1}$ hybrids were selected randomly for data recording of twelve characters (Table 1). The formula used to estimate combining ability analysis was carried out according to Model-I, Method-2 of Griffing (1956).

\section{Results and Discussion}

The analysis of variance for combining ability revealed that the mean square due to GCA and SCA were significant for all the characters studied. This indicated that both additive and non-additive type of gene effects played an important role in the inheritance of all these traits under studied. The magnitude of GCA and SCA variances revealed that the SCA variances were higher than their respective GCA variances for all the characters except for days to first picking. The potence ratio less than unity confirmed the preponderance of non-additive gene action for all the traits studied (except days to first picking) and emphasized the utility of hybrid breeding approach to exploit existing heterosis in sponge gourd. The predominance of nonadditive gene action for fruit yield and its component traits were also reported by Naliyadhra et al., (2007a), Sanandia et al., (2007) and Sanandia et al., (2008) in sponge gourd.

The summary of general combining ability effects of the parents (Table 2) revealed that none of the parents was found to be good general combiner for all the characters. An overall appraisal of gca effects revealed that parents ASGS 08-37, ASGS 06-30, JSG 05-7 and Pusa Chikni were good general combiners for fruit yield per vine and some of its components, whereas ASGS 08-38 and ASGS 08-39 were poor combiners for fruit yield per vine. ASGS 08-37 ranked first in gca effects for fruit yield per vine, node to first female flower, days to first picking while stood third in respect of gca effects for number of fruits per vine. ASGS 06-30 exhibited second position in gca effect for fruit yield per vine but secured first position for fruit fly infestation (\%). Parent JSG 05-7 exhibited third position in gca effect for fruit yield per vine while stood second in respect of gca effects for days to open first female flower. ASGS 08-37 and ASGS 08-40 both showed significant gca effects in desirable direction for node to first female flower and days to first picking. Among these traits most of the traits were related to earliness. Hence, ASGS 08-37 and ASGS 08-40 could be utilized for earliness in sponge gourd. Thus, ASGS 08-37, ASGS 06-30, JSG 05-7 and Pusa Chikni were good general combiner for fruit yield and its components and ASGS 08-37 and ASGS 0840 for earliness, which may be utilized in future crossing programme to generate the genetic variability for effective selection to develop high fruit yielding genotypes with earliness in sponge gourd. High general combining ability effects mostly contribute additive gene effects or additive $\mathrm{x}$ additive interaction effects (Griffing, 1956 a and 1956 b) and represent fixable portion of genetic variation. In view of this, ASGS 08-37, ASGS 06-30, JSG 05-7 and Pusa Chikni offer the best possibilities of exploitation for the development of improved lines with enhanced yielding ability in sponge gourd.

The summary of specific combining ability analysis of the crosses (Table 3) revealed that the highest yielding hybrid Pusa Chikni $\mathrm{x}$ ASGS 08-37 had also registered highest sca effect for fruit yield per vine On the other hand, the cross ASGS 08-37 x ASGS 08-39 had second highest sca for fruit yield per vine which was due to good $x$ poor general combiner parents. This indicated the presence of epistatic gene action and such deviation could be attributed to the genetic diversity in the form of heterozygous loci. 
Table.1 Analysis of variance for combining ability for fruit yield and its contributing characters in sponge gourd

\begin{tabular}{|c|c|c|c|c|c|c|c|c|c|c|c|c|c|}
\hline $\begin{array}{l}\text { Source of } \\
\text { variation }\end{array}$ & df & $\begin{array}{c}\text { Days to } \\
\text { open } \\
\text { first } \\
\text { female } \\
\text { flower }\end{array}$ & $\begin{array}{l}\text { Node to } \\
\text { first } \\
\text { female } \\
\text { flower }\end{array}$ & $\begin{array}{c}\text { Node } \\
\text { to first } \\
\text { male } \\
\text { flower }\end{array}$ & $\begin{array}{c}\text { Days } \\
\text { to } \\
\text { first } \\
\text { pickin } \\
\mathrm{g}\end{array}$ & $\begin{array}{l}\text { Length } \\
\text { of vine } \\
\text { (m) }\end{array}$ & $\begin{array}{l}\text { No. of } \\
\text { primary } \\
\text { branches } \\
\text { per vine }\end{array}$ & $\begin{array}{c}\text { No. of } \\
\text { fruits } \\
\text { per vine }\end{array}$ & $\begin{array}{c}\text { Ten fruit } \\
\text { weight (g) }\end{array}$ & $\begin{array}{l}\text { Fruit } \\
\text { length } \\
\text { fruit } \\
\text { (cm) }\end{array}$ & $\begin{array}{l}\text { Fruit } \\
\text { girth } \\
(\mathrm{cm})\end{array}$ & $\begin{array}{l}\text { Fruit } \\
\text { yield } \\
\text { per } \\
\text { vine } \\
\text { (kg) }\end{array}$ & $\begin{array}{c}\text { Fruit fly } \\
\text { infestati } \\
\text { on }(\%)\end{array}$ \\
\hline gca & 9 & $10.35 * *$ & $1.20 * *$ & $0.37 * *$ & $1.00 *$ & $0.15 * *$ & $0.12 * *$ & 0.38 & $12034.20 * *$ & $11.32 * *$ & $0.43^{*}$ & $0.64 * *$ & $9.90 * *$ \\
\hline sca & 45 & $7.08 * *$ & $2.00 * *$ & $0.44 * *$ & $2.30 *$ & $0.11 * *$ & $0.09 * *$ & $0.44 * *$ & $22431.76^{* * *}$ & $3.97 * *$ & $0.20 *$ & $0.15 * *$ & $15.99 * *$ \\
\hline Error & 108 & 3.08 & 0.43 & 0.14 & 2.31 & 0.03 & 0.08 & 0.21 & 1084.91 & 1.39 & 0.25 & 0.07 & 3.37 \\
\hline$\square^{2}$ gca & & 0.60 & 0.06 & 0.01 & 0.10 & 0.00 & 0.00 & 0.01 & 912.44 & 0.82 & 0.01 & 0.00 & 0.54 \\
\hline$\square^{2} \mathrm{sca}$ & & 3.99 & 1.56 & 0.30 & 0.01 & 0.07 & 0.07 & 0.23 & 21346.83 & 2.58 & 0.05 & 0.02 & 12.61 \\
\hline$\square^{2} \mathrm{gca} / \square^{2} \mathrm{sca}$ & & 0.15 & 0.04 & 0.06 & 2.87 & 0.13 & 0.10 & 0.06 & 0.04 & 0.32 & 0.29 & 0.090 & 0.04 \\
\hline
\end{tabular}

$*, * *$ significant at $5 \%$ and $1 \%$, respectively

Table.2 Estimates of general combining ability effects for fruit yield and its contributing characters in sponge gourd

\begin{tabular}{|c|c|c|c|c|c|c|c|c|c|c|c|c|}
\hline Parents & $\begin{array}{c}\text { Days to } \\
\text { open first } \\
\text { female } \\
\text { flower }\end{array}$ & $\begin{array}{l}\text { Node to } \\
\text { first } \\
\text { female } \\
\text { flower }\end{array}$ & $\begin{array}{c}\text { Node } \\
\text { to first } \\
\text { male } \\
\text { flower }\end{array}$ & $\begin{array}{c}\text { Days to } \\
\text { first } \\
\text { picking }\end{array}$ & $\begin{array}{c}\text { Length } \\
\text { of vine } \\
\text { (m) }\end{array}$ & $\begin{array}{c}\text { Number of } \\
\text { primary } \\
\text { branches } \\
\text { per vine }\end{array}$ & $\begin{array}{c}\text { Number } \\
\text { of } \\
\text { fruits } \\
\text { per vine }\end{array}$ & $\begin{array}{l}\text { Ten fruit } \\
\text { weight } \\
\text { (g) }\end{array}$ & $\begin{array}{c}\text { Fruit } \\
\text { length } \\
\text { fruit } \\
\text { (cm) }\end{array}$ & $\begin{array}{l}\text { Fruit } \\
\text { girth } \\
(\mathrm{cm})\end{array}$ & $\begin{array}{c}\text { Fruit } \\
\text { yield } \\
\text { per vine } \\
\text { (kg) }\end{array}$ & $\begin{array}{c}\text { Fruit fly } \\
\text { infestatio } \\
\text { n (\%) }\end{array}$ \\
\hline P.Chikni & $1.05^{*}$ & 0.24 & 0.17 & $0.24^{*}$ & $0.12 *$ & $0.12 * *$ & $0.32 *$ & $37.03 * *$ & $1.62 * *$ & -0.12 & $0.47 * *$ & $-1.52 * *$ \\
\hline GSG 1 & 0.24 & $-0.70 * *$ & $-0.21 *$ & 0.14 & $0.11^{*}$ & $0.14 * *$ & $-0.66 * *$ & 9.97 & $1.99 * *$ & -0.19 & -0.02 & $1.13^{*}$ \\
\hline ASGS 08-40 & $-1.02 *$ & $-0.60 * *$ & 0.03 & $-0.76 * *$ & $0.50 * *$ & $0.07 *$ & 0.14 & 7.66 & $1.04 * *$ & -0.18 & -0.19 & $-1.71 * *$ \\
\hline ASGS 08-38 & -0.49 & $0.46^{*}$ & $0.26^{*}$ & $0.26^{*}$ & $-0.19 * *$ & $-0.12 *$ & $0.51 * *$ & $23.67 * *$ & $-1.25 * *$ & $-0.60 * *$ & $-0.53 * *$ & 0.23 \\
\hline ASGS 08-37 & $1.61 * *$ & $-0.92 *$ & -0.03 & $-0.83 * *$ & 0.07 & 0.03 & $0.39 * *$ & 12.76 & $-1.39 * *$ & 0.02 & $0.75 * *$ & 0.53 \\
\hline ASGS 08-39 & $-1.79 * *$ & -0.04 & $-0.31 * *$ & 0.08 & $-0.59 *$ & 0.01 & 0.09 & $60.97 * *$ & -0.30 & $0.49 * *$ & $-0.46^{* *}$ & 0.55 \\
\hline ASGS 06-30 & -0.12 & $0.38 *$ & 0.14 & $0.46^{*}$ & $-0.78 * *$ & -0.04 & -0.11 & $34.09 * *$ & -0.27 & 0.01 & $0.67 * *$ & $-1.81 * *$ \\
\hline ASGS 02-12 & $1.70 * *$ & $0.39 *$ & -0.10 & 0.05 & 0.03 & -0.07 & $0.73 * *$ & $-39.93 * *$ & -0.53 & $0.54 * *$ & -0.16 & $1.46 * *$ \\
\hline JSG 05-7 & $-1.17 *$ & -0.01 & $0.27 *$ & $0.28 *$ & -0.03 & $-0.30 * *$ & $-0.33 * *$ & -13.36 & 0.07 & -0.07 & $0.64 * *$ & $-1.34 * *$ \\
\hline JSG 05-4 & -0.01 & -0.27 & 0.08 & -0.38 & 0.06 & $-0.14 * *$ & -0.13 & -10.92 & $-0.91 * *$ & -0.09 & -0.16 & 0.41 \\
\hline SE(gi) & 0.48 & 0.17 & 0.10 & 0.41 & 0.05 & 0.03 & 0.12 & 9.02 & 0.32 & 0.13 & 0.02 & 0.50 \\
\hline
\end{tabular}

$*$,** significant at $5 \%$ and $1 \%$, respectively 
Table.3 Three best crosses showing estimates of SCA effects along with status of GCA effects of parents for different characters in sponge gourd

\begin{tabular}{|c|c|c|c|}
\hline Characters & Cross & $\begin{array}{l}\text { SCA } \\
\text { effect }\end{array}$ & $\begin{array}{l}\text { GCA } \\
\text { effect }\end{array}$ \\
\hline \multirow[t]{3}{*}{ Days to open first female flower } & ASGS 08-38 x JSG 05-4 & $-4.94 * *$ & A X A \\
\hline & ASGS 08-37 x ASGS 06-30 & $-4.77 * *$ & P X A \\
\hline & ASGS 08-37 x ASGS 08-39 & $-3.19 * *$ & P X G \\
\hline \multirow[t]{3}{*}{ Node to first female flower } & P.Chikni x ASGS 08-37 & $-2.52 * *$ & $\mathrm{~A} X \mathrm{X}$ \\
\hline & P.Chikni x JSG 05-7 & $-2.40 * *$ & $\mathrm{GX} A$ \\
\hline & ASGS 08-40 x ASGS 08-38 & $-91.47 * *$ & GX A \\
\hline \multirow[t]{3}{*}{ Node to first male flower } & P.Chikni x JSG 05-4 & $-1.33 * *$ & A X A \\
\hline & ASGS 08-40 x JSG 05-4 & -1.09 & A X A \\
\hline & GSG 1 x ASGS 08-39 & $-0.76^{*}$ & $\mathrm{GX} \mathrm{G}$ \\
\hline \multirow[t]{3}{*}{ Days to first picking } & P.Chikni x ASGS 08-38 & $-3.59 * *$ & P X P \\
\hline & P.Chikni x ASGS 06-30 & $-2.74 * *$ & P X P \\
\hline & GSG 1x ASGS 02-12 & $-2.72 * *$ & $\mathrm{~A} X \mathrm{~A}$ \\
\hline \multirow[t]{3}{*}{ Length of vine (m) } & ASGS 02-12 x JSG 05-7 & $0.56 * *$ & A X A \\
\hline & ASGS 08-40 x JSG 05-7 & $0.44 * *$ & GX A \\
\hline & P. Chikni x GSG 1 & $0.42 * *$ & $\mathrm{GX} \mathrm{G}$ \\
\hline \multirow[t]{3}{*}{ No. of primary branches per vine } & GSG 1 x JSG 05-4 & $0.46^{* *}$ & $\mathrm{G} \times \mathrm{P}$ \\
\hline & P.Chikni x ASGS 08-38 & $0.43 * *$ & GX P \\
\hline & ASGS 08-40 x ASGS 02-12 & $0.40 * *$ & $\mathrm{GX} \mathrm{A}$ \\
\hline \multirow[t]{3}{*}{ Number of fruits per vine } & P. Chikni x ASGS 06-30 & $1.52 * *$ & GX A \\
\hline & ASGS 02-12 x JSG 05-4 & $1.31 * *$ & $\mathrm{G} \times \mathrm{A}$ \\
\hline & ASGS 08-39 x ASGS 02-12 & $1.10 * *$ & $\mathrm{AX} \mathrm{X}$ \\
\hline \multirow[t]{3}{*}{ Ten fruit weight (g) } & ASGS 06-30 x JSG 05-7 & $384.58 * *$ & $\mathrm{GX} \mathrm{A}$ \\
\hline & P.Chikni x ASGS 06-30 & $334.19 * *$ & GX G \\
\hline & ASGS 02-12 x JSG 05-4 & $265.49 * *$ & P X A \\
\hline \multirow[t]{3}{*}{ Fruit length (cm) } & ASGS 08-40 x JSG 05-7 & $5.09 * *$ & P X A \\
\hline & GSG 1 x ASGS 08-37 & $3.78 * *$ & G X P \\
\hline & GSG 1 x ASGS 08-38 & $2.99 * *$ & GX P \\
\hline \multirow[t]{3}{*}{ Fruit girth (cm) } & ASGS 08-38 x ASGS 02-12 & $0.63 * *$ & $\mathrm{~A} X \mathrm{G}$ \\
\hline & ASGS 08-38 x JSG 05-4 & $0.55 * *$ & A X A \\
\hline & P.Chikni x ASGS 08-39 & $0.50 * *$ & $\mathrm{~A} X \mathrm{X}$ \\
\hline \multirow[t]{3}{*}{ Fruit yield per vine (kg) } & P.Chikni x ASGS 08-37 & $0.40 * *$ & $\mathrm{G} \times \mathrm{G}$ \\
\hline & ASGS 08-37 x ASGS 08-39 & $0.39 * *$ & GX P \\
\hline & ASGS 08-40 x JSG 05-4 & $0.36 * *$ & A X A \\
\hline \multirow[t]{3}{*}{ Fruit fly infestation (\%) } & ASGS 08-38 x ASGS 02-12 & $-6.95 * *$ & A X P \\
\hline & ASGS 08-40 x ASGS 08-37 & $-4.64 * *$ & GX A \\
\hline & GSG 1 x ASGS 08-40 & $-4.59 * *$ & P X G \\
\hline
\end{tabular}


Pusa Chikni x ASGS 08-37 (good x good), Pusa Chikni x ASGS 06-30 (good x good) and Pusa Chikni x JSG 05-7 (good x good) involving both high combining parents offer till better possibilities of exploitation as these are expected to yield stable segregants in the advance generations and thus, need further exploitation in the breeding programme. The best specific combinations for different characters were either good x poor, poor x poor, average $\mathrm{x}$ poor, good $\mathrm{x}$ average, average $\mathrm{x}$ average and vice versa general combiners. This suggested that information on gca effects should be supplemented by sca effects and hybrid performance of cross combinations to predict the transgressive type possibly made available in segregating generations. Selection is rapid if gca effects of parents and sca effects of crosses are in same direction. If crosses showing high sca effects involve at least one parent possessing good gca effects and high per se performance, they could be exploited for practical breeding. However, Chaudhary et al., (1974) stated that high sca effects would not necessarily mean a high performance by the hybrid and the estimation of sca effects.

In the present investigation, estimates of combining ability variances revealed that both additive and non-additive variances were important in the inheritance of different characters. Under a situation where both additive and non-additive gene effects are important, biparental matings as well as mating of selected plants in early segregating generations should be attempted in developing potential populations having optimum levels of homozygosity and heterozygosity. Further, where both additive and non-additive genetic effects are present, transgressive segregants can also be isolated alternative inter-mating and selfing. However, due to prepordance of non- additive gene effects for fruit yield and its most of the component traits, it would be worthwhile to exploit particular crosses in heterosis breeding programme as the production of hybrid varieties are practically feasible and easy in sponge gourd.

\section{Acknowledgement}

We are very much thankful to Staff of department of Genetics and Plant Breeding, JAU, Junagadh for their kindly help

\section{References}

Chaudhary, B. D., Singh, R. K. and Kakav, S. N., (1974). Estimation of genetic parameters in barley (Hardium vulgare L.). Full, half and quarter diallel analysis. Theort. Appl. Genet., 45: 192-196.

Griffing, B. (1956 a). Concept of general and specific combining ability in relation to diallel crossing. Aust. J. Bio. Sci., 9: 453459.

Griffing, B., (1956b). A generalized treatment of diallel crosses in quanititative inheritance. Heredity, 10: 31-50.

Naliyadhara, M. V., Dhaduk, L. K., Barad, A. V., Purohit, V. L. and Vachhani J. H., (2007a). Heterosis for fruit yield and its components in sponge gourd (Luffa cylindrica (Roem.) L.), Natnl. J. Pl. Improv., 9: 132-135.

Sanandia, S. T., Mehta, D. R., Tarpara, V. D. and Naliyadhara, M. V., (2007). Heterosis breeding in sponge gourd (Luffa cylindrica (Roem.) L.). Int. J. of Bioscience Reporter, 5: 629-633.

Sanandia, S. T., Mehta, D. R., Tarpara, V. D., and Dhaduk, L. K., (2008). Studies on relative heterosis, heterobeltiosis and inbreeding depression on fruit yield and its attributes in sponge gourd (Luffa cylindrica (Roem.) L.). Natnl. J. Pl. Improv., 10: 106-109.

\section{How to cite this article:}

Sanjeev Kumar, V.J. Bhatiya and Sanjay Kumar. 2018. Combining Ability Analysis in Sponge gourd [Luffa cylindrica (Roem.) L.]. Int.J.Curr.Microbiol.App.Sci. 7(05): 3577-3581. doi: https://doi.org/10.20546/ijcmas.2018.705.413 